\title{
n........................
}

HIV Infection and the Cardiovascular System 


\section{Advances in Cardiology}

\section{Vol. 40}

Jeffrey S. Borer New York, N.Y. 


\section{HIV Infection and the Cardiovascular System}

Volume Editor

Giuseppe Barbaro Rome

24 figures, 13 in color, and 25 tables, 2003

KARGER 


\section{Advances in Cardiology}

\section{Jeffrey S. Borer, MD}

Gladys and Roland Harriman Professor of Cardiovascular Medicine

Chief, Division of Cardiovascular Pathophysiology

Co-Director, The Howard Gilman Institute for Valvular Heart Diseases

Weill Medical College

Cornell University

New York, NY 10021 (USA)

\section{Library of Congress Cataloging-in-Publication Data}

HIV infection and the cardiovascular system / volume editor, Giuseppe Barbaro.

p. ; cm. - (Advances in cardiology, ISSN 0065-2326; v. 40)

Includes bibliographical references and index.

ISBN 3-8055-7606-4 (hard cover : alk. paper)

1. Cardiovascular system-Diseases. 2. AIDS (Disease)-Complications. 3. Cardiological manifestations of general diseases. I. Barbaro, Giuseppe. II. Series.

[DNLM: 1. Cardiovascular Diseases-etiology. 2. HIV Infections-complications, WG 120 H676 2003]

RC681.A25A38 vol. 40

[RC678]

$616.1^{\prime} 2 \mathrm{~s}-\mathrm{dc} 22$

[616.1]

2003054639

Bibliographic Indices. This publication is listed in bibliographic services, including Current Contents ${ }^{\circledR}$ and Index Medicus.

Drug Dosage. The authors and the publisher have exerted every effort to ensure that drug selection and dosage set forth in this text are in accord with current recommendations and practice at the time of publication. However, in view of ongoing research, changes in government regulations, and the constant flow of information relating to drug therapy and drug reactions, the reader is urged to check the package insert for each drug for any change in indications and dosage and for added warnings and precautions. This is particularly important when the recommended agent is a new and/or infrequently employed drug.

All rights reserved. No part of this publication may be translated into other languages, reproduced or utilized in any form or by any means electronic or mechanical, including photocopying, recording, microcopying, or by any information storage and retrieval system, without permission in writing from the publisher.

(C) Copyright 2003 by S. Karger AG, P.O. Box, CH-4009 Basel (Switzerland)

www.karger.com

Printed in Switzerland on acid-free paper by Reinhardt Druck, Basel

ISSN 0065-2326

ISBN 3-8055-7606-4 


\section{Contents}

\section{Foreword}

Fiala, M. (Los Angeles, Calif.)

1 HAART and Cardiology - Current Controversies and Consequences Hoffmann, C. (Kiel); Jaeger, H. (Munich)

Epidemiology, Pathogenesis and Molecular Biology

15 Evolution of the Involvement of the Cardiovascular System in HIV Infection

Barbaro, G. (Rome)

23 Cardiovascular Pathology in AIDS

Klatt, E.C. (Tallahassee, Fla.)

49 Pathogenesis of HIV-Associated Cardiovascular Disease Barbaro, G. (Rome)

71 The Pathogenesis of HIV-Associated Pulmonary Hypertension Klings, E.S.; Farber, H.W. (Boston, Mass.)

83 Pathogenesis of the HAART-Associated Metabolic Syndrome Behrens, G.M.N. (Hannover, Parkville); Stoll, M.; Schmidt, R.E. (Hannover)

97 HIV-Associated Lipodystrophy: Pathogenesis and Clinical Features Barbaro, G. (Rome)

Clinical and Therapeutic Insights

105 Assessment of Autonomic and Cardiovascular Function in HIV Disease Brownley, K.A. (Chapel Hill, N.C.); Hurwitz, B.E. (Coral Gables, Fla.)

140 Atherosclerosis and HIV Infection: Diagnosis and Treatment Mooser, V. (King of Prussia, Pa.) 
151 Coronary Heart Disease in HIV-Infected Individuals

Vittecoq, D.; Escaut, L.; Merad M.; Teicher, E.; Monsuez, J.J. (Villejuif);

Chironi, G. (Paris)

163 Coronary Artery Disease and Stroke in HIV-Infected Patients:

Prevention and Pharmacological Therapy

Boccara, F.; Cohen, A. (Paris)

185 Vasculitic Syndromes in HIV-Infected Patients

Barbaro, G. (Rome)

197 HIV-Associated Pulmonary Hypertension: Diagnosis and Treatment Burkart, K.M.; Farber, H.W. (Boston, Mass.)

208 HIV-Associated Cardiovascular Complication in HIV-Infected Children

Bonnet, D. (Paris)

219 Cardiac Surgery in the Patient with Human Immunodeficiency Virus Frater, R.W.M.; Comacho, M.; Frymus, M.; Soeiro, R.; Zingman, B.S. (Bronx, N.Y.)

226 Guidelines for the Prevention and Management of Cardiovascular Complications in HIV-Infected Patients Receiving HAART:

The Pavia Consensus Statement

Barbaro, G. (Rome)

Appendix

233 Interactions between Antiretroviral Agents and Drugs Commonly Used to Treat Cardiovascular Diseases According to the Pavia Consensus Statement

Barbaro, G. (Rome)

241 Author Index

242 Subject Index 


\title{
Foreword
}

\author{
Milan Fiala \\ Department of Medicine, West LA VA Medical Center and UCLA School of \\ Medicine, Los Angeles, Calif., USA
}

The causes of cardiomyopathies are poorly understood, and most cases coming to heart transplantation are idiopathic. Although enteroviral RNA sequences have been detected in explanted tissues, the significance of those sequences is uncertain, and the individual roles of potentially cardiotropic viruses, coxsackie- and echoviruses, adenoviruses, cytomegalovirus and Epstein-Barr virus are difficult to assess. It comes as a revelation that HIV-1 is rapidly becoming a prominent cause not only of an epidemic of cardiomyopathy but also of coronary heart disease, peripheral vascular disease, vasculitis, cardiac neoplasms, endocarditis and pericarditis. Although opportunistic infections account for a minority of these complications in HIV-1-positive patients, the majority may be due directly or indirectly to the effects of HIV-1 or highly active antiretroviral therapy (HAART) regimens, as described in the new book edited by G. Barbaro Human Immunodeficiency Virus Infection and the Cardiovascular System.

Dr. Barbaro has assembled a strong group of basic and clinical scientists to describe the realm of cardiovascular morbidities in patients with AIDS. The presentations in part 1, 'Epidemiology, Pathogenesis and Molecular Biology' effortlessly transit from pathology to molecular mechanisms. The chapters concerning the pathophysiology of increased cardiovascular risk in AIDS patients of lipodystrophy, atherosclerosis, coronary heart disease, stroke, vasculitic syndromes and pulmonary hypertension include a discussion of potential mechanisms relating cardiovascular disease to HIV infection. The complication 'HIV/HAART-associated dyslipidemic lipodystrophy' is proposed to depend upon 'systemic steatosis'. Although still largely speculative, this 
hypothesis will certainly stimulate novel therapeutic strategies in both AIDS and non-AIDS patients with cardiovascular disease.

In the chapter on the pathogenesis of HIV cardiomyopathy, Dr. Barbaro emphasizes the role of inflammatory mechanisms, inducible nitric oxide synthase, tumor necrosis factor $\alpha$ and other cytokines. Such mechanisms are increasingly recognized as being elicited by HIV-1 infection of macrophages in the AIDS heart and producing cardiomyocyte apoptosis [1]. Our work as well as that of other groups has shown that viral envelope protein gp120 is the main culprit. The new book on HIV-1 and the cardiovascular system will be of interest to a broad audience, which needs to learn about the epidemic of HIV cardiovascular disease.

\section{Reference}

1 Twu C, Liu NQ, Popik W, Bukrinsky M, Sayre J, Roberts J, Rania S, Bramhandam V, Roos KP, MacLellan WR, Fiala M: Cardiomyocytes undergo apoptosis in human immunodeficiency virus cardiomyopathy through mitochondrion- and death receptor-controlled pathways. Proc Natl Acad Sci USA 2002;99:14386-14391.

Milan Fiala

Department of Medicine

West LA VA Medical Center and UCLA School of Medicine

Los Angeles, CA 90095 (USA)

Tel. +1 310206 6392, Fax +1 310825 1678, E-Mail fiala@ucla.edu 